\title{
Kedudukan Hukum Saksi Instrumentair Terkait Keautentikan Akta Notaris
}

\author{
Ni Putu Anggelina ${ }^{1}$ \\ ${ }^{1}$ Program Studi Magister (S2) Kenotariatan Fakultas Hukum Universitas Udayana, Bali- \\ Indonesia, E-mail : E-mail: niputu.angel@gmail.com
}

\begin{tabular}{l}
\hline Info Artikel \\
\hline Keywords : \\
Witness instrumentair, \\
authenticity, deed, notary \\
\\
Kata kunci: \\
Saksi instrumentair, \\
keotentikan, akta, notaris \\
Corresponding Author: \\
Ni Putu Angelina \\
E-mail: \\
\hline
\end{tabular}

\begin{abstract}
The legal status of a Notary employee in his capacity is a witness of the Instrumentair to support the validity of an authentic deed which is inseparable and has legal consequences for the deed of the Notary. Notary deed that raises the law causes the Notary employee to work as a witness instrument in the deed to be the party responsible and responsible for the law that appears. The legal issue in this journal is the Responsibility for the accountability of instruments in the deed of a Notary? And how to place the legal position in the instrumentation in terms of supporting the Notary deed related to the Notary's responsibility to keep the confidentiality of the deed which is made by him based on Article 16 Paragraph (1) Letter F and Article 40 of the UUJN Amendment?, This article is analyzed by normative legal research methods with a study of Article 16 paragraph (1) letter $f$ UUJN Changes that still involve obscurity of legal norms. The purpose of this study is to examine the accountability of the instrumentair in the deed of the Notary and also provide understanding in terms of the legal position of the instrumentair selection related to the authenticity of the Notary deed. The results of the study through the journal can prove the lawsuits related to the substance of the deed whose signing involved him, remembering his capacity only employees who are functioned by a Notary to prepare the deed. The legal position of viewing related to the occupation of the Notary keeps the confidentiality of the deed whose production is made based on Article 16 paragraph (1) letter $f$ and Article 40 of the UUJN. Therefore the instrumentair witness cannot apply Article 322 of the Criminal Code because his capacity as an election is not bound by professional ownership. Witness instructors who do not support the confidentiality of Notary documents.
\end{abstract}

\footnotetext{
Abstrak

Status hukum pegawai Notaris dalam kapasitasnya menjadi saksi Instrumentair guna mendukung sahnya suatu akta autentik merupakan hal yang tak terpisahkan dan memiliki konsekwensi hukum terhadap akta Notaris. Akta Notaris yang menimbulkan persoalan hukum menyebabkan pegawai Notaris yang berfungsi sebagai saksi instrumentair dalam akta menjadi pihak yang dianggap tahu dan bertanggung jawab atas persoalan hukum yang muncul. Isu hukum dalam jurnal ini adalah Bagaimanakah tanggungjawab saksi instrumentair dalam akta Notaris? Dan
} 
DOI :

10.24843/AC.2018.v03.i03.p1

0

\section{Pendahuluan}

Notaris awal keberadaanya di Indonesia diatur melalui Peraturan Jabatan Notaris staatsblad 1860-3 (untuk selanjutnya disebut sebagai PJN).Notaris Indonesia seiring berjalannya waktusistem hukumnya semakin berkembang seiring majunya Negara Indonesia. Tidak sesuainya PJN dengan kemajuan jaman dilakukan pembenahan oleh pemerintah yang diganti dengan Undang-Undang Nomor 30 Tahun 2004 tentang Jabatan Notaris (selanjutnya disebut UUJN) dan mengalami perubahan kembali dengan diratifikasinya Undang-Undang Nomor 2 Tahun 2014 tentang Perubahan atas Undang-Undang Nomor 30 Tahun 2004 tentang Jabatan Notaris (selanjutnya disingkat UUJNPerubahan).

Pasal 1 angka 1 UUJN Perubahan ditentukan bahwa "Notaris merupakan pejabat umum yang mempunyai kewenangan membuat akta autentik serta memunyai kewenangan lain sesuai yang ditentukan menurut undang lainnya dan undangundang ini".

Dasar hukum Notaris menjalankan kewenangan yang berhubungan dengan akta autentik terdapat dalam ketentuan Pasal 15 UUJN Perubahan. ${ }^{1}$ Notaris dalam menjalankan tugasnya dibantu oleh pegawai Notaris. Posisi pegawai Notaris dalam pembuatan akta autentik fungsinya sebagai saksi instrumentair yang dalam hal ini

\footnotetext{
1Sujanayasa, I. K., Ibrahim, R., \& Ariawan, I. G. K.. (2016). Status Hukum Saksi Instrumentair Terkait Pembuatan Akta Notaris Serta Relevansinya Terhadap Ketentuan Pasal 16 Ayat (1) UndangUndang Nomor 30 Tahun 2004 Tentang Jabatan Notaris. Acta Comitas, h.284
} 
dapat memberikan perlindungan hukum kepada Notaris apabila akta autentik yang dibuatnya menimbulkan persoalan hukum atau para pihak yang menjadi penghadap dalam akta menghindar tentang kebenaran keterangan yang diberikan dalam akta. Seorang saksi instrumenter harus memenuhi ketentuan Pasal 40 ayat (2) UUJN Perubahan. ${ }^{2}$ Kewajiban untuk adanya saksi dalam pembuatan akta autentik disyaratkan pada Pasal 16 ayat (1) huruf m jo Pasal 40 UUJN Perubahan.

Notaris dengan tegas tidak diperkenankan menjadikan saksi seseorang dalam peresmian akta jika tidak memenuhi ketentuan pasal diatas.

UUJN Perubahan pada dasarnya tidak menentukan dengan tegas bentuk-bentuk saksi yang disyaratkandalam akta autentik. Dalam kajian kenotarisan oleh para sarjanadikenal adanya dua bentuk saksi. Tan Thong Kiesalah satunya mengemukakan bentuk saksi yang dimaksud adalah saksi pengenal dan saksi instrumentair. ${ }^{3}$

Adapun Saksi Intrumentair adalah saksi yang melihat secara langsung dan ikut dalam prosedur penandatanganan akta sesuai yang disyratkan UUJN Perubahan. Saksi instrumentair harus hadir saat dibuat dan ditandatanganinya akta Notaris. Saksi pengenal ialah seorang saksi yang mengenalkan para pihak yang menjadi penghadap dalam akta sekurang-kurangnya berusia 18 tahun atau sudah menikah serta memiliki kematangan diri dalam bersikap atau cakap hukum.

Pegawai Notaris adalah pihak yang dapat berperan sebagai saksi instrumentair atau saksi akta. Notaris melangsungkan pekerjaannya saat membuat akta menempatkan pegawai Notaris menjadi saksi ketika akta akan ditandatangani. Pegawai Notaris dalam fungsinya sebagai saksi instrumentair bisa menyampaikan kesaksian sudah sesuainya syarat formal pembentukan suatu akta yang mengacu pada ketentuan Pasal 16 ayat (1) huruf $m$ jo Pasal 40 UUJN Perubahan.

Keberadaan saksi instrumentair tetap diperlukan dalam pembentukan akta Notaris karena perannya dapat membantu Notaris melaksanakan jabatannya menjadi lebih aman khususnya dalam hal pembuktian ketika akta yang telah disahkan oleh Notaris terjadi persoalan hukum.

Tertandatanganinya akta Notaris dengan sempurna memiliki arti bahwa akta tersebut telah diakui kebenarannya dan memiliki nilai kebenraran yang sah dalam pembuktian dipengadilan atau atentik. Akta autentik tetap autentik dalam hal para pihak tetap mengakui kebenaran isi akta yang dibuatnya dan tidak ada pihak lain yang membuktikan ketidak benaran isi akta tersebut. ${ }^{4}$ Pengaturan mengenai keamanan hukum pegawai Notaris dalam fungsinya sebagai saksi instrumentair tidak ada pengaturannya di UUJN ataupun UUJN Perubahan. Perbuatan hukum pegawai Notaris menjadi saksi instrumentair berkaitan dengan di sahkannya akta Notaris merupakan domain Hukum Kenotariatan, sehingga diperlukan adanya suatu

${ }^{2}$ Hutapea, H. N. R. (2016). Fungsi Saksi Instrumentair Kaitannya Dengan Akta Notaris Menurut Hukum Nasional. Premise Law Journal, h. 113

${ }^{3}$ Tan Thong Kie. (2000). Studi Notariat \& Serba Serbi Praktek Notaris. Jakarta : Ichtiar Baru Van Hoeve, h. 268

4Teguh Samudera. (2004). Pembuktian Pada Hukum Acara Perdata. Bandung:Alumni, h. 49 
pengaturan baik dalam UUJN dan UUJN Perubahan agar dapat memberikan keamanan hukum.

Akta autentik yang dibuat oleh Notaris memiliki sifat kerahasiaan dan harus dijaga protokolnya kecuali hukum menentukan berbeda yang dasar hukumnya mengacu pada Pasal 16 ayat (1) huruf f UUJN Perubahan. Adapun isu hukum pada jurnal penelitian ini yang dapat penulis deskripsikan yaitu pegawai Notaris sebagai saksi Instrumentair pengaturan hukumnya tidak jelas terkait keharusannya merahasiakan isi akta Notaris dan apabila terjadi permasalahan terkait akta Notaris apakah seorang saksi instrumentair juga dapat dimintai pertanggungjawabannya. Sesuai dengan pemaparan latar belakang yang telah penulis uraikan, menarik bagi penulis mengambil tema penelitian "Kedudukan Hukum Saksi Instrumentair Terkait Keautentikan Akta Notaris." Adapun isu hukum yang dibahas adalah : Bagaimanakah tanggungjawab saksi instrumentair dalam akta Notaris? Dan bagaimanakah kedudukan hukum saksi instrumentair dalam hal mendukung keautentikan akta Notaris terkait adanya kewajiban Notaris menyimpan kerahasiaan akta yang pembuatannya dilakukan olehnya berdasarkan Pasal 16 Ayat (1) Huruf F dan Pasal 40 UUJN Perubahan?

Penulisan Jurnal penelitian ini bertujuan untuk mengkaji dan meningkatkan kualitas ilmu Hukum Kenotariatan yang utamanya berkaitan dengan kedudukan saksi instrumentair dalam akta Notaris. Tujuan khusus penelitian ini adalah mengkaji secara mendalam tanggungjawab saksi instrumentair dalam akta Notaris serta memberikan pemahaman dalam hal kedudukan hukum saksi instrumentair terkait dengan keautentikan akta Notaris.

\section{Metode Penelitian}

Jurnal penelitian ini dianalisis dengan penelitian hukum normatif yang kajian bahan hukumnya bersumber dari peraturan perundang-undangan serta literatur-literatur yang relevan dengan isu hukum penelitian ini. ${ }^{5}$ Penelitian ini didasari adanya kekaburan aturan hukum yang terdapat pada ketentuan Pasal 16 ayat (1) huruf f UUJN Perubahan dalam hal kewajiban Notaris merahasiakan akta namun saksi instrumentair juga mengetahui isi akta tersebut dan tidak ada ketentuan dalam UUJN Perubahan dan UUJN bahwa saksi instrumentair juga wajib merahasiakan isi akta Notaris.

Agar penelitian ini memberikan hasil penelitian ilmiah yang bisa dipertanggungjawabkan secara keilmuan, penelitian ini dianalisa dengan menggunakan pendekatan analitis, pendekatan konsep, dan pendekatan perundangundangan. Pendekatan analitis adalah pendekatan yang didasari dengan menemukan makna yang terdapat pada terminologi-terminologi hukum yang ada pada peraturan perundang-undangan sehingga peneliti mendapat arti terkini dari terminologiterminologi hukum, serta diuji kegunaanya dalam ranah praktikal dengan mengkajinya pada putusan-putusan hukum.

Pendekatan konsep adalah pendekatan yang dalam ilmu hukum bisa digunakan sebagai tolak ukur dalam memberikan analisa penelitian hukum serta hasilnya dapat

5Soekanto, Soerjono. \& Mamudji, Sri. (2001). Penelitian Hukum Normatif: Suatu Tinjauan Singkat. Jakarta. PT : Raja Grafindo Persada, h. 24 
memberikan berbagai macam konsep terhadap suatu fakta hukum. Pendekatan perundang-undangan ialah pendekatan yang menggunakan dan mengkaji semua peraturan perundang-undangan yang memiliki keterkaitan dengan isu hukum dalam kajian jurnal penelitian ini.

Sumber bahan hukum pada jurnal ilmiah ini meliputi bahan hukum primer dengan mengacu pada ketentuan peraturan perundang-undangan yang berlaku dan memiliki keterkaitan dengan peneitian ini, bahan hukum sekunder terdiri atas buku-buku hukum, jurnal hukum, karya tulis hukum, atau pandangan ahli hukum. Bahan hukum tersier terdiri dari kamus enslikopedi. Melalui jurnal penelitian ini bahan hukum diatas yang telah terkumpuldianalisis kemudian disusun secara sistematis dan komperhensif.

Teknik pengumpulan bahan hukum pada jurnal penelitian ini terhadap bahan-bahan hukum yang diperlukan dan akan digunakan dalam jurnal penelitian, teknik pengumpulannya memakai teknik sistem kartu (card system). Teknik analisis bahan hukum yang diterapkan guna menganalisa bahan hukum yang sudah terkumpul dalam jurnal penelitian ini memakai teknik, deskripsi, interpretasi, sistematisasi, dan evaluasi.

\section{Hasil dan Pembahasan}

\subsection{Tanggungjawab Saksi Instrumentair Dalam Akta Notaris}

Akta Notaris dibuat dengan dasar kehendak para pihak yang hadir menghadap kepada Notaris. Tanpa adanya keinginan para pihak untuk menuangkan kesepakatan mereka kedalam akta, maka perjanjian yang dibuat dihadapan Notaris dalam akta tidak akan pernah terlaksana. Notaris dalam melaksanakan jabatannya menuangkan kehendak para pihak kedalam akta harus mengacu pada ketentuan hukum yang berlakuagar tidak terjadi cacat hukum terhdap produk hukum yang dihasilkan Notaris dan aktanya tetap dikualisifikasikan sebagai akta autentik. ${ }^{6}$

Akta Notaris substansinya membuat kehendak penghadap yang datang pada Notaris, bukan kemauan Notaris. Notaris fungsinya dalam konteks ini berada ditengah-tengah dalam arti tidak memihak dan meluruskan apabila ada hal yang salah dan tidak semsestinya menjadi isi akta.

Dalam menjalankan praktik kenotarisannya, Notaris diwajibkan untuk mengarahkan para pihak yang bersangkutan dalam akta menjadi paham terkait akta yang dibuatnya dan membacakan isi akta dihadapannya. Akta autentik Notaris berfungsi sebagai alat bukti yang sempurna artinya adalah semua substansi yang tercatat pada akta harus diakui benar oleh hakim apabila tidak ada pihak yang mempersoalkan ata tersebut.

Bila akta Notaris yang dibuat oleh orang yang berkepentingan pada akta dinilai belum mewakili apa yang diharapkan atau diinginkan adanya perubahan, orang yang berkepentingan dengan sepakat secara bersamaan datang menghadap Notaris guna membuat akta pembatalan atau perubahan terkait akta yang telah dibuatnya.Dalam ranah hukum kenotariatan yang sesuai terkait akta Notaris dan Notaris, bila akta

${ }^{6}$ Adjie, Habib. (2009). Sanksi Perdata dan Administrasi Notaris Sebagai Pejabat Publik. Bandung: Refika Aditama. Selanjutnya disebut Habib Adjie I, h. 84 
Notaris dipersoalkan oleh orang-orang yang berkepentingan, pihak yang berkepentingan harus hadir kembali ke Notaris untuk dibuatkan akta pembatalan. Dengan adanya akta pembatalan secara hukum pihak yang berkepentingan pada akta sudah tidak terikat lagi pada sebuah perikatan dan konsekwensinya pihak yang berkepentingan bertanggung jawab terhadap adanya pembatalan tersebut.

Dalam sistem hukum Indonesia saksi berfungsi sebagai salah satu alat bukti yang sah dan dalam Hukum Acara Perdata diartikan seseorang yang memberi keterangan, baik dengan lisan atau tertulis ataupun dengan menggunakan tanda tangan, yang memberikan keterangan tentang apa yang disaksikannya yang dapat berupa perbuatan/tindakan dari orang lain atau suatu situasi dari adanya peristiwa yang terjadi.

Hukum Kenotarisan mengklasifikasikan dua jenis saksi yang terdiri dari saksi intrumentair dan saksi pengenal. Saksi instrumentair (InstrumentaireGetulgen) merupakan saksi yang memiliki tugas mengenai akta para pihak (partij) dan harus hadir saat dibuatnya akta, dibacakannya akta dan ditandatanganinya akta. Saksi instrumentair mempunyai kewajiban ikut menandatangani akta yang dibuat oleh para pihak. Saksi pengenal (Attestterend Betulgen) merupakan saksi yang fungsinya mengenalkan para penghadap kepada Notaris.

Notaris wajib menghadirkan 2 (dua) orang saksi akta setiap dibacakan dan ditandanganinya akta Notaris. Saksi akta ini berasal dari pegawai Notaris. Dengan hadirnya saksi akta,mereka dapat memberikan kesaksian bahwa formalitasdalam pembuatan akta yang ditentukan oleh undang-undang telah dicapai. ${ }^{7}$ Pegawai Notaris diharuskan memiliki kemampuan untuk mencocokan identitas para pihak yang berkepentingan yang namanya akan tercatat dalam akta sebelum akta ditandatangani, serta tidak terlepas juga dari petunjuk dan arahan Notaris. Keberadaan saksi instrumentair dalam setiap pembuatan akta Notaris sangat diharuskan.Peran saksi instrumenterdalam suatu akta Notaris yaitu memberikan keamanan bagi Notaris apabila akta yang dibuat dipersoalkan pihak yang berperan sebagai komparisi akta atau pihak ketiga, serta memiliki fungsi sebagai sebagai alat bukti mengingat saksi instrumentair dapat memberikan keterangan dipersidangan dan hal ini bisa diklasifikasikan sebagai alat bukti dengan saksi atau pengakuan. Sifat dan keberadaan saksi instrumentair menjadi saksi ialah mendengar dibacakannya akat oleh Notaris serta melihat langsung penandatanaganan akta namun tidak harus memahami substansi akta yang dibacakan oleh Notaris terkait akta dan tidak mempunyai keharusan menyimpan isi akta melalui ingatannya. ${ }^{8}$

Pegawai Notaris yang berfungsi sebagai saksi instrumentair diharuskan hadir langsung pada saat diresmikannya akta yaitu pembacaan akta oleh Notaris serta bertanggung jawab penuh terhadap apa yang diminta dan ditugaskan Notaris namun tidak memiliki tanggung jawab terkait isi akta yang ia tandatangani mengingat sifat dan kedudukannya sebagai pegawai yang difungsikan Notaris sebatas menyiapkan

${ }^{7}$ Nanda, L. D. (2016). Perlindungan Hukum Terhadap Saksi Instrumenter Dalam Akta Notaris Yang Aktanya Menjadi Objek Perkara Pidana Di Pengadilan. Premise Law Journal, h. 186

${ }^{8}$ Kusumaningrum, I. A. K., Wairocana, I. G. N., \& Suartha, I. D.M. (2018). Kewajiban Saksi Instrumenter Merahasiakan Isi Akta Berdasarkan Undang-Undang Jabatan Notaris. Acta Comitas., h. 237-246. 
akta. Eksistensi saksiintrumentair merupakan hal yang disyaratkan UUJNPerubahan dan UUJN guna memberikan nilai autentitisitas akta Notaris.

Saksi Instrumentair dalam fungsinya sebagai saksi akta memiliki kewajiban yang cukup besar khususnya saat diresmikannya akta Notaris. Saksi instrumentair berkewajiban melihat disusunnya akta Notaris, dibacakannya akta, serta ditandatanganinya akta oleh pihak yang berkepeningan dihadapan Notaris sesuai yang ditentukan oleh undang-undang guna memenuhi nilai autentisitas akta. Tanggungjawab saksi instrumentair dalam akta Notaris bahwa saksi instrumentair tidak bisa dituntut secara hukum terkait substansi akta yang penandatanganannya melibatkan dirinya, megingat kapasitasnya hanya pegawai yang difungsikan oleh Notaris untuk mempersiapkan akta. Notaris bertanggungjawab penuh terhadap substansi akta meskipun dalam hal keabsahan akta disyaratkan adanya saksi yang diatur dalam ketentuan Pasal 40 ayat (1) UUJNPerubahan. Apabila dikemudian hari terjadi kasus hukum terhadap akta Notaris, Notaris harus bertanggungjawab atas isi aktanya mengingat saat pembuatan akta ia berinteraksi langsung dengan pihak berkepentingan yang namanya tercatat pada akta yang dibuatnya.

Pegawai Notaris sebagai saksi instrumentair tidak perlu memahami isi akta dan tidak bertanggungjawab terhadap isi akta namun bertanggungjawab saat peresmian akta serta formalitas akta yang ditugaskan Notaris seperti menyiapkan draft akta, penyesuaian data pribadi melalui verifikasi data, menyiapkan surat yang memiliki relevansi terhadap para pihak yang namanya akan tercatat diakta, turut melihat langsung dibacakan, ditandatanganinya akta, serta menandatangani akta terkait fungsinya sebagai saksi instrumentair. Masih adanya kekaburan norma hukum dalam UUJNP berkaitan dengan tanggungjawab saksi instrumentair, pembuat undangundang hendaknya memberikan pembenahan terkait kejelasan saksi Instrumentair dan apa saja yang menjadi hak dan kewajibannya dalam akta autentik. Pembuat undangundang hendaknya menyelaraskan dengan Teori Kepastian Hukum Van Apeldoorn yang mengatakan bahwa kepastian hukum memiliki dua segi yaitu dapat ditentukannya hukum dalam hal yang konkret dan keamanan hukum. 9 Tanggungjawab saksi instrumentair ini hendaknya meliputi dua hal yang harus ada dalam karakter penormaan didalam suatu aturan undang-undang yaitu ditentukan dengan konkret dan jelas hal yang diperlukan oleh hukum yang mampu menjangkau seiring kemajuan jaman kedepannya dan aman secara hukum. Kepastian hukum merupakan ciri yang tidak dapat dipisahkan dari hukum, terutama untuk norma hukum tertulis. Hukum tanpa nilai kepastian akan kehilangan makna karena tidak dapat dijadikan sebagai pedoman perilaku bagi semua orang.

\subsection{Kedudukan Hukum Saksi Instrumentair Dalam Mendukung Keautentikan Akta Notaris Terkait Adanya Kewajiban Notaris Menyimpan Kerahasiaan Akta Yang Pembuatannya Dilakukan Olehnya Berdasarkan Pasal 16 Ayat (1) Huruf F Dan Pasal 40 UUJN Perubahan.}

Notaris adalah pejabat umum yang tidak sama dengan pejabat umum lainnya. Notaris mempunyai kewenangan dalam pembuatan akta autentik tentang segala hal

\footnotetext{
${ }^{9}$ Hasan, A. Madjedi. (2009). Kontrak Minyak dan Gas Bumi Berazas Keadilan dan Kepastian Hukum. Jakarta: Fikahati Aneska, h. 10
} 
perbuatan, perjanjian, dan penetapan yang lebih spesifiknya diatur dalam ketentuan Pasal 15 UUJN Perubahan. Profesi Notaris diangkat oleh pemerintah guna membantu Negara dibidang Hukum Keperdataan dan diperlukan oleh masyarakat untuk menjawab keperluan masyarakat terkait bantuan hukum yang netral dan seimbang dalam pembuatan akta autentik.

Akta autentik sesuai yang ditentukan dalam Pasal 1868 KUH Perdataformatnya disyaratkan oleh hukum, pembuatannya dilakukan langsung didepan pejabat umum yang memiliki kewenangan dalam hal itu dan bertempat dimana akta itu dibuat. Terpenuhinya substansi ketentuan Pasal 1868 KUH Perdata dapat digunakan sebagai alat bukti dalam pembuktian di pengadilan sesuai ketentuan Pasal 1867 KUH Perdata.

Notaris dalam menjalankan kewenangan dan kewajibannya tentunya membutuhkan pekerja atau pegawai Notaris untuk mendukung dalam pembuatan akta autentik di kantor Notaris. Peran pegawai Notaris penting guna mendukung suksesnya profesi seorang Notaris memberikan pelayanan jasa hukum. Hubungan hukum antara pegawai dan Notaris merupakan keterkaitan yang diatur oleh hukum serta menimbulkan hak dan kewajiban. ${ }^{10}$.

Kemajuan jaman yang diiringi dengan berkembangnya tehnologi yang semakin canggih menyebabkan alat bukti dalam perkara pidana ataupun perdata semakin berkembang dengan diakuinya alat bukti elektronik atau data yang tersimpan maupun terekam sebagai instrumen kebenaran yang sah pada sistem hukum di Indonesia. ${ }^{11}$

Akta autentik memiliki nilai pembuktian yang sempurna mengenai apa yang termuat didalamnya untuk orang yang bersangkutan termasuk para ahli warisnya atau terhadap orang-orang yang memperoleh hak dari mereka. Hal ini ditentukan di ketentuan Pasal 1870 KUH Perdata, Pasal 165 HIR, dan Pasal 285 RBG. Akta autentik berfungsi sebagai instrumen kebenaran yang mengikat tentang suatu hal yang ditulis pada akta dan oleh hakim harus diyakini memiliki nilai kebenaran dalam hal tidak ada pihak lain yang menggugat adanya kesalahan pada akta tersebut.

Format akta autentik yang pengerjaannyaoleh Notaris terdapat pada Pasal 38 UUJN Perubahan dan UUJN. Akta autentik Notaris memiliki kekhususan secara hukumnya :

1. Akta Notaris pembentukannya harus menyesuaikan dengan UUJNP dan UUJN.

2. Dibuatnya akta Notaris didasari atas permintaan orang yang bersangkutan.

3. Walaupun pada akta tercatat nama Notaris, namun Notaris kapasitasnya bukan pihak yang berafiliasi dengan orang yang bersangkutan yang namanyatercatat pada akta.

4. Memiliki nilai kebenaran yang lengkap. Orang yang bersangkutan dalam pembuatan akta terikat melalui adanya akta Notaris dan isi akta tidak bisa dimaknai berbeda selainyang tercatat pada akta.

5. Dibatalkan dan hilangnya daya ikat akta Notaris bisa terlaksana bila terjadi kesepakatan antara orang bersangkutan yang namanya tercatat pada akta, atau

${ }^{10}$ Wisnuwardhani, D. A. (2017). Implementasi Hak Pekerja Dalam Upah Di Kantor Notaris. Jurnal Cakrawala Hukum. Vol.8, No.1 Juni 2017, h. 33-43

${ }^{11}$ Habib Adjie. (2013). Kebatalan Dan Pembatalan Akta Notaris. Jakarta: Refika Aditama. Selanjutnya disebut Habib Adjie II, h. 5 
orang berangkutan yang merasa keberatan dapat mengajukan permohonan ke pengadilan disertai alasan tertentu yang dapat membuktikan bisa dibatalkannya akta tersebut.

Akta autentik memiliki nilai pembuktian yang sempurna sehingga dapat dipastikan para pihak terikat dengan adanya akta yang dibuatnya di Notaris selama tidak ada pihak-pihak yang dapat membuktikan kesalahan pada akta itu disertai dengan putusan pengadilan yang memiliki kekuatan hukum tetap.

Akta autentik sebutan bagi produk hukum yang dihasilkan oleh pejabat tertentu yang dikualifikasikan sebagai pejabat umum seperti Notaris, Pejabat Pembuat Akta Tanah (PPAT), Pejabat Lelang dan Pegawai Kantor Catatan Sipil yang jenis aktanya menyesuaikan dengan kewenangan yang diberikan oleh hukum. ${ }^{12}$

Nilai autentisitas akta Notaris tolak ukurnya mengacu pada UUJNPerubahan dan UUJN. Akta Notaris dikatakan autentik bila :

a. Akta Notaris pembuatannya dilakukan dihadapan seseorang yang memiliki kewenangan dalam hal itu.

b. Mempunyai tanggal pasti dalam hal kapan dibuatnya akta.

c. Mempunyai data pasti terkait siapa pejabat yang menandatangani dan memuat tanda tangan orang yang bersangkutan sendiri pada akta.

d. Notaris telah memberikan sarannya saat pembuatan akta belum dilangsungkan dalam hal mana yang dibolehkan oleh ketentuan undang-undang yang berlaku dan mana yang tidak.

e. Jika ada pihak yang mengingkari kebenaran isi akta, maka ia harus membuktikan kebenaran isi akta.

f. Akta Notaris bersifat rahasia.

Perjanjian yang memberikan keamanan secara hukum bagi pihak yang bersangkutan idealnya dibentuk melalui akta Notaris. Mekanisme ditandatanganinya pejanjian yang dibuat dengan akta Notaris ditentukan dengan tegas pada ketentuan Pasal 44 Ayat (1) UUJNPerubahan: "setelah pembacaan akta, penandatanganan akta dilakukan oleh pihak yang bersangkutan, saksi dan Notaris, kecuali pihak yang bersangkutan tidak mampu memberikan tanda tangan harus disertai alasannya". Alasan tersebut harus dinyatakan secara pasti pada bagian ahir akta. Tertandatangannya akta oleh pihak yang berangkutan serta melibatkan Notaris didalamya memiliki makna kesepakatan yang mereka sahkan dengan akta Notaris menjadi sebuah undang-undang baginya.

Pada hakekatnya Notaris akan memprioritaskan pegawainya sebagai saksi yang dicatatkan pada akta-akta yang pembuatannya dilakukan olehnya sendiri. Tidak ada aturan hukum yang tidak memperbolehkan hal itu selama persyaratan menjadi saksi terpenuhi dan hal ini diatur dalam ketentuan Pasal 40 UUJNP. Saksi yang tercatat pada akta Notaris merupakan saksi instrumentair yang disyaratkan oleh undang-undang. Kehadiran 2 (dua) orang saksi instrumenter adalah mutlak, namun bukan berarti harus 2 (dua) orang, boleh lebih jika situasi menginginkan. ${ }^{13}$

\footnotetext{
${ }^{12}$ Maisyarah, I. (2016). Analisis Yuridis Tentang Kedudukan saksi Dalam Pembuatan Akta Notariil Menurut Hukum Islam Dan Undang-undang Jabatan Notaris (UUJN). Premise Law Journal, h.142 ${ }^{13}$ Sutrisno. (2007). Komentar Undang-Undang Jabatan Notaris Buku II. Medan, h. 35-37
} 
Pasal 40 ayat (1) UUJN merupakan dasar hukum syarat formal harus terpenuhinya 2 (dua) orang saksi yang identitasnya disebutkan secara tegas pada akhir akta. Peneliti melalui teori kepastian hukum menganalisis kedudukan saksi instrumentair yang tercatat pada akta Notaris berfungsi untuk menjaga keabsahan akta dan autentisitasnya mengingat jika syarat saksi instrumentair ini tidak disesuaikan di akta Notaris, maka dengan mengacu pada kentuan Pasal 41 UUJNPerubahan konsekwensi hukumnya terjadi penurunan atau degradasi dalam hal nilai pembuktiannya menjadi akta dibawah tangan. Akta Notaris diharuskan untuk bisa menjamin kepastian hukum tentang suatu peristiwa hukum seperti sewa menyewa, pewarisan dan lain-lain yang dibuat benar-benar sesuai fakta yang sebenarnya dan telah memenuhi standar prosedur dalam pembuatan akta.

Ketentuan dalam Pasal 171 HIR menyatakan keterangan saksi adalah suatu hal yang dilihatnya, apa yang didengarnya, atau dirasakan sendiri. Setiap keterangan saksi memiliki keharusan tentang alasan-alasan apa yang yang menjadi penyebabnya dan suatu cara diketahuinya sesuatu serta dijelaskan langsung darinya. Pemikiran khusus yang terbentuk melalui pikirannya tidak dilihat suatu kesaksian. Saksi akta Notaris yang berasal dari pegawai Notaris adalah saksi-saksi yang dilibatkan pada pembentukan akta. Oleh sebab itu, saksi akta Notaris disebut sebagai saksi Instrumentair (instrumentair getuigen). Para saksi dalam akta Notaris memberikan kesaksian dengan cara menempatkan tandatangannya pada akta, dan memberi keterangannya terkait telah terpenuhinya kesesuaian formalitas akta yang disyaratkan Undang-Undang Jabatan Notaris. ${ }^{14}$

Kedudukan saksi instrumentair dalam fungsinya untuk memenuhi persyaratan formalitas akta Notaris ditentukan pada Pasal 38 ayat (4) huruf c UUJN Nomor 30 Tahun 2004 tentang Jabatan Notaris, Pasal 1868 KUH Perdata serta Pasal 40 ayat (1) UUJN Perubahan. Akta Notaris disebut telah lengkap bila semua persyaratan formalitas dipenuhi sehingga akta Notaris memiliki nilai pembuktian yang sempurna serta keberadaan saksi akta di akta Notaris bisa dipertanggungjawabkan secara hukum.

Kedudukan Saksi instrumentair terkait adanya kewajiban Notaris menyimpan kerahasiaan semua hal berkaitan dengan akta yang pembuatannya dilakukan olehnya berdasarkan Pasal 16 ayat (1) huruf f UUJN Perubahan dan Pasal 40 UUJN Perubahan masih terdapat kekaburan norma hukum. Agar tidak menimbulkan kekaburan hukum dalam pembuatan undang-undang hendaknya undang-undang dibuat dengan menggunakan Teorinya H.L.A. Hart yang dalam pemikirannya membagi sistem hukum menjadi dua yaitu primary rules dan secondary rules. Hal tersebut merupakan pusat dari sistem hukum dan harus ada. Primery rules adalah mengatur tentang kewajiban manusia dalam tindakannya serta apa yang tidak diperbolehkan. ${ }^{15}$ Pada primary rules ada dua model. Jenis pertama yang didalamnya terdapat norma sosial yang keberadaannya dengan dipenuhinya beberapa persyaratan; Pertama adanya peraturan keseragaman perilaku didalam kelompok masyarakat (umum). Kedua,

\footnotetext{
${ }^{14}$ Habib Adjie. (2011). Merajut Pemikiran Dalam Dunia Notaris \& PPAT. Citra Aditya Bakti: Bandung. Selanjutnya disebut Habib Adjie III, h. 9

${ }^{15}$ Hart, H.L.A. dalam Atmaja, I.D.G., dan Budiartha, I.N.P. (2018). Teori-Teori Hukum, Malang: Setara Press, h. 41
} 
peraturan itu dirasa sebagai kewajiban dalam suatu (sebagian besar) dalam anggota kelompok sosial yang relevan. ${ }^{16}$ Model kedua disebut Hart dengan secondary rules adalah aturan tentang aturan yang bila di rinci meliputi :

1. Peraturan yang menetapkan dengan tegas peraturan mana yang dapat di anggap sah;

2. Dengan siapa dan dalam hal bagaimana dapat dirubah;

3. Dengan siapa dan bagaimana dapat dikuatkan,dipaksakan/ditegakan.

Saksi instrumentair terkait adanya kewajiban Notaris menyimpan kerahasiaan semua hal berkaitan dengan akta yang pembuatannya dilakukan olehnya berdasarkan Pasal 16 ayat (1) huruf f UUJN Perubahan dan Pasal 40 UUJN Perubahan secara hukum kedudukannya tidak diwajibkan secara pasti harus menjaga kerahasiaan substansi akta. Oleh sebab itu terhadap saksi akta tidak bisa diterapkan Pasal 322 KUHPkarena kapasitasnya sebagai saksi tidak melekat jabatan profesi. Saksi instrumentair yang tidak menjaga kerahasiaan dokumen Notaris perbuatannya diklasifikasikan perbuatan melawan hukum.

\section{Kesimpulan}

Tanggungjawab saksi instrumentair dalam akta Notaris bahwa saksi instrumentair tidak bisa dituntut secara hukum terkait substansi akta yang penandatanganannya melibatkan dirinya, megingat kapasitasnya hanya pegawai yang difungsikan oleh Notaris untuk mempersiapkan akta.

Kedudukan hukum saksi instrumentair dalam hal mendukung keautentikan akta Notaris terkait adanya kewajiban Notaris menyimpan kerahasiaan akta yang pembuatannya dilakukan olehnya berdasarkan Pasal 16 ayat (1) huruf $\mathrm{f}$ dan Pasal 40 UUJN Perubahan adalah tidak diwajibkan secara pasti harus menjaga kerahasiaan substansi akta. Oleh sebab itu terhadap saksi instrumentair tidak bisa diterapkan Pasal 322 KUHP karena kapasitasnya sebagai saksi tidak melekat jabatan profesi. Saksi instrumentair yang tidak menjaga kerahasiaan dokumen Notaris perbuatannya diklasifikasikan perbuatan melawan hukum.

Bagi para Notaris hendaknya selalu memberikan petunjuk kepada pegawainya dan selalu tetap memantau kinerja pegawainya sebagai seorang saksi instrumentair dalam akta Notaris agar nantinya tidak sampai menimbulkan permasalahan yang mengakibatkan akta menjadi terdegradasi menjadi akta di bawah tangan. Saksi instrumentair hendaknya selalu berhati-hati dalam melaksanakan tugasnya sebagai karyawan Notaris dalam membantu mempersiapkan dokumen-dokumen hukum termasuk akta Notaris dan memastikan kebenaran identitas para penghadap dalam akta Notaris.

\section{Daftar Pustaka}

\section{Buku}

Habib Adjie. (2009). Sanksi Perdata dan Administrasi Notaris Sebagai Pejabat Publik. Bandung: Refika Aditama

Habib Adjie. (2011). Merajut Pemikiran Dalam Dunia Notaris \& PPAT.Bandung: Citra Aditya Bakti 
Habib Adjie. (2013). Kebatalan Dan Pembatalan Akta Notaris. Jakarta: Refika Aditama

Hasan, A. Madjedi. (2009). Kontrak Minyak dan Gas Bumi Berazas Keadilan dan Kepastian Hukum. Jakarta: Fikahati Aneska

Hart, H.L.A. dalam Atmaja, I.D.G., dan Budiartha, I.N.P. (2018). Teori-Teori Hukum. Malang: Setara Press

Soekanto, Soerjono, dan Mamudji, Sri. (2007). Penelitian Hukum Normatif : Suatu Tinjauan Singkat, Jakarta: PT. Raja Grafindo Persada

Sutrisno. (2007). Komentar Undang-Undang Jabatan Notaris Buku II. Medan

Tan Thong Kie. (2000). Studi Notariat \& Serba Serbi Praktek Notaris. Jakarta: Ichtiar Baru Van Hoeve

Teguh Samudera. (2004). Hukum Pembuktian Dalam Acara Perdata. Bandung: Alumni.

\section{Jurnal}

Hutapea, H. N. R. (2016). Kedudukan Saksi Instrumenter dalam Pembuatan Akta Notaris dalam Hukum Nasional. Premise Law Journal

Kusumaningrum, I. A. K., Wairocana, I. G. N., \& Suartha, I. D. M. Kewajiban Saksi Instrumenter. (2018). Merahasiakan Isi Akta Berdasarkan Undang-Undang Jabatan Notaris. Acta Comitas

Maisyarah, I. (2016). Analisis Yuridis Tentang Kedudukansaksi Dalam Pembuatan Akta Notariil Menurut Hukum Islam Dan Undang-Undang Jabatan Notaris (UUJN). Premise Law Journal

Nanda, L. D. (2016). Perlindungan Hukum Terhadap Saksi Instrumenter Dalam Akta Notaris Yang Aktanya Menjadi Objek Perkara Pidana Di Pengadilan. Premise Law Journal

Sujanayasa, I. K., Ibrahim, R., \&Ariawan, I. G. K.. (2016). Status Hukum Saksi Instrumentair Terkait Pembuatan Akta Notaris Serta Relevansinya Terhadap Ketentuan Pasal 16 Ayat (1) Undang-Undang Nomor 30 Tahun 2004 Tentang Jabatan Notaris. Acta Comitas

Wisnuwardhani, D. A. (2017). Implementasi Hak Pekerja Dalam Hal Upah Di Kantor Notaris. Jurnal Cakrawala Hukum 